\section{$\underset{\substack{\text { hommes } \\ \text { \& migrations }}}{ }$}

\section{Hommes \& migrations}

Revue française de référence sur les dynamiques

migratoires

$1301 \mid 2013$

Migrations et mondes ruraux

\title{
Wassyla Tamzali, Histoires minuscules des révolutions arabes
}

Paris, Chèvre Feuille étoilée, 2012, 360 pages, 19 euros

\section{Mustapha Harzoune}

\section{(2) OpenEdition}

1 Journals

Édition électronique

URL : http://journals.openedition.org/hommesmigrations/1967

DOI : $10.4000 /$ hommesmigrations. 1967

ISSN : 2262-3353

Éditeur

Musée national de l'histoire de l'immigration

Édition imprimée

Date de publication : 1 janvier 2013

Pagination : 208-209

ISBN : 978-2-919040-21-6

ISSN : 1142-852X

Référence électronique

Mustapha Harzoune, "Wassyla Tamzali, Histoires minuscules des révolutions arabes 》, Hommes \& migrations [En ligne], 1301 | 2013, mis en ligne le 29 mai 2013, consulté le 22 septembre 2020. URL : http://journals.openedition.org/hommesmigrations/1967; DOI : https://doi.org/10.4000/ hommesmigrations.1967

Ce document a été généré automatiquement le 22 septembre 2020.

Tous droits réservés 


\title{
Wassyla Tamzali, Histoires minuscules des révolutions arabes
}

\author{
Paris, Chèvre Feuille étoilée, 2012, 360 pages, 19 euros
}

\author{
Mustapha Harzoune
}

\section{RÉFÉRENCE}

Wassyla Tamzali, Histoires minuscules des révolutions arabes, Paris, Chèvre Feuille étoilée, 2012, 360 pages, $19 €$

1 Wassyla Tamzali fut avocate à Alger avant de travailler pour l'Unesco. Militante, féministe et écrivaine, elle est l'auteure de plusieurs essais, notamment Une éducation algérienne (Gallimard, Folio, 2007) et Une femme en colère. Lettre d'Alger aux Européens désabusés, (Gallimard, 2009). Elle coordonne ici ce recueil d'Histoires minuscules des révolutions arabes qui ne devait être, à l'origine, qu'un simple dossier commandé par la revue Étoiles d'encre. Au fil du temps et des rencontres, le dossier est devenu un livre comprenant 41 contributions d'auteurs algériens, syriens, égyptiens, libanais, tunisiens, marocains, à cheval sur plusieurs pays, plusieurs continents, et autant d'axes et de thèmes de réflexion.

2 À la réception des textes, Wassyla Tamzali confie son étonnement. Elle, la féministe attentive aux relations entre hommes et femmes, plus d'une fois sans doute confrontée aux questions des corps et de la sexualité, consciente que ce thème est, à l'instar des questions identitaires, central pour le devenir de ces sociétés, dit avoir été surprise par "la prégnance si forte du sexe". Il faudrait y voir la dénonciation de "la haine des femmes" qui se manifeste jusque dans la sexualité masculine. Il s'agirait aussi de revendiquer une liberté d'expression pleine et entière : l'amour est un fait, pas une poésie courtoise. De manière plus radicale, cette "prégnance" traduirait enfin les rapports étroits entretenus entre sexe et pouvoir, entre violence sexuelle et exercice du pouvoir.

3 Le parti pris d'évoquer les révolutions arabes via ces "histoires minuscules" témoigne de la volonté de pointer la dimension humaine des dynamiques à l'œuvre, les 
responsabilités individuelles aussi, le refus des eschatologies et une méfiance à l'endroit des leaders et des verticalités politiques. Les peuples, arabes et berbères, ont déjà donné! La force de ce "minuscule" est de rendre l'infiniment grand des possibles, du divers et du composite, des paradoxes aussi qui traversent l'ensemble de ces mouvements.

Un premier danger pointe déjà : l'oubli, la disparition des traces des insurrections. D'où l'importance du dire, des mots et des fictions. Dans ces histoires enchevêtrées, l'Algérie est un miroir. Ce pays si prompt à glorifier le passé lointain semble frappé d'amnésie quand il faut remonter aux souvenirs récents, ceux d'octobre 88, ou évoquer les victimes de la décennie 1990 (voir par exemple le combat d'un Nazim Mekbel, fils du journaliste Saïd Mekbel assassiné le 3 décembre 1994). Il faut dire aussi car "ce qui est essentiel, c'est que cela a eu lieu. Cela pourrait donc advenir de nouveau".

Wassyla Tamzali décrit un vieux militaire cloué dans son fauteuil roulant, qui se demande "où est passé le peuple algérien". La cécité du grabataire traduit le mépris des dirigeants pour leur peuple: peuple "ingrat" et sans courage, inexistant et donc insignifiant. Le "mépris", la "rage", la "haine" agitent encore le corps fossile, empoisonné jusqu'à la moelle par le goutte-à-goutte d'une histoire officielle dégorgeant de mystique nationaliste, de paranoïa et de rejet de l'étranger. Deux vieilles blessures ne cessent de tirailler ce corps et cette âme malades : Nawel sa petite-fille, son "échec", qui l'a "trahi" en partant pour la France, et une balle que sa vieille carcasse traîne depuis la guerre. La balle n'est pas française.... 